\title{
Dedykowane normy konstytucyjne i dobre praktyki w realizacji polityki publicznej wobec sektora wiedzy
}

\begin{abstract}
Streszczenie
Sfera wartości i związane z nimi uwarunkowania polityki to zagadnienia aktualne w naukach społecznych. Autor prezentuje dobre praktyki w zakresie partnerstwa pomiędzy aktorami w procesie kreowania, realizacji i ewaluacji polityki publicznej, podkreślając ich fundamenty aksjologiczne. Ma to zwłaszcza zastosowanie wobec sektora wiedzy jako obszaru szczególnie wrażliwego na gruncie instytucjonalnym ze względu na duże aspiracje zaangażowanych twórców.

Artykuł przedstawia pojęcie sektora wiedzy na tle określeń powiązanych, takich jak: społeczeństwo wiedzy, społeczeństwo informacyjne, gospodarka oparta na wiedzy, zarządzanie wiedzą, a także formułuje pewne zalecenia dotyczące rozwoju tego sektora. Autor prezentuje strukturę podmiotową sektora wiedzy w ujęciu funkcjonalnym, z podkreśleniem postulatu większej integracji instytucjonalnej w działaniach prorozwojowych.

W artykule prezentowane są normy konstytucyjne, a na ich tle postulowane zasady dialogu społecznego i partnerstwa jako zasady fundamentalne w sektorze wiedzy. Autor analizuje misję państwa, podkreślając znaczenie jego roli jako gwaranta tych reguł.

Artykuł przedstawia instrumentarium polityki publicznej wobec sektora wiedzy, z podkreśleniem znaczenia zasad i dobrych praktyk we współdziałaniu realizatorów polityki publicznej z kreatorami wiedzy jako ich partnerami środowiskowymi.
\end{abstract}

Słowa kluczowe: polityka publiczna, sektor wiedzy, normy, dobre praktyki 


\title{
Constitutional Norms and Good Practices Dedicated to The Implementation of Public Policy Towards The Knowledge Sector
}

\begin{abstract}
Sphere of values and related to them determinants of policy making constitute current issues in the social sciences. The author presents good practices in terms of partnerships among actors in the process of creation, implementation and evaluation of public policy, emphasizing their axiological foundations. This is primarily applicable in the knowledge sector which is an area particularly sensitive on the institutional ground because of great aspirations of the creators engaged.

The article explains the concept of the knowledge sector using a group of related terms such as knowledge society, information society, knowledge-based economy, knowledge management and formulates a number of recommendations for development of this sector.

The author presents the institutional structure of the knowledge sector in functional terms with emphasis on the demand of their greater integration in the pro-development activities.

Subsequently, there is a presentation of constitutional norms, based on which the social dialogue and partnership are suggested as fundamental principles in the knowledge sector. The author examines the mission of the state emphasizing the importance of its role as a guarantor of these values and rules.

Finally, the article presents the instruments of public policy towards the knowledge sector focusing on the importance of the principles and best practices in cooperation between public policy makers and their social partners - the creators of knowledge.
\end{abstract}

Keywords: public policy, knowledge sector, norms, good practices

Badania nad polityką publiczną, ze względu na wiele rodzajów polityki sektorowej, wymagają podejścia interdyscyplinarnego. Procesy formułowania treści polityki publicznej oraz implementacji i ewaluacji różnych jej dziedzin angażują rozmaite dyscypliny nauki, m.in. społeczne, ekonomiczne, techniczne, prawnicze, a także wiedzę właściwą dla danego sektora. Nie możemy przy tym tracić z pola widzenia istotnego znaczenia utylitarnego charakteru badań sektorowych prowadzonych 
w ramach dyscypliny nauki o polityce publicznej, które sytuują ją przede wszystkim wśród nauk stosowanych ${ }^{1}$.

Wybór sektora jako przedmiotu analizy może mieć charakter branżowy/resortowy. Może także w pewnych warunkach odnosić się do badań o charakterze gałęziowym. Poszczególne sektory jako przedmiot badań możemy też identyfikować, odwołując się do działów administracji rządowej² ${ }^{2}$ W szczególności, pojęcie sektora w tym rozumieniu może integrować wybrane działy, pod warunkiem że tworzą one wspólny, zintegrowany obszar funkcjonalny.

Takim, zasługującym na wyróżnienie, obszarem jest tzw. sektor wiedzy. Charakteryzuje go pewna swoistość reguł i uwarunkowań działania, wśród których na szczególną uwagę zasługują zasady odnoszące się do sfery ideowej. W tym artykule analizujemy te $\mathrm{z}$ nich, które wynikają z norm konstytucyjnych i dobrych praktyk o fundamentach mających charakter aksjologiczny. Powinny one wywierać istotny wpływ na treści, formę i styl polityki publicznej wobec sektora wiedzy. Dla jego rozwoju fundamentalne znaczenie ma respektowanie wymogów twórczości i autonomii instytucjonalnej oraz charakter relacji z partnerami środowiskowymi.

Sfera wartości i aksjologiczne uwarunkowania polityki to zagadnienia aktualne w naukach o polityce. W tym artykule autor nawiązuje do prac P. Łyżwy ${ }^{3}$ i M. Suchanka ${ }^{4}$ ogłoszonych w ostatnich latach, powołując je dla podkreślenia znaczenia fundamentów aksjologicznych jako podstawy dobrych praktyk w zakresie partnerstwa pomiędzy aktorami w procesie projektowania, realizacji i ewaluacji polityki publicznej. Ma to szczególne zastosowanie wobec sektora wiedzy jako obszaru szczególnie wrażliwego ze względów instytucjonalnych, w związku z aspiracjami środowisk twórczych zaangażowanych w kreowanie nowej wiedzy.

\section{Sektor wiedzy i pojęcia powiązane}

Słowa kluczowe i pojęcia powiązane odnoszące się do zakresu znaczeniowego „sektor wiedzy” to m.in. wiedza, społeczeństwo wiedzy, zarządzanie wiedzą, gospodarka oparta na wiedzy, społeczeństwo informacyjne, Europa wiedzy itp.

\footnotetext{
${ }^{1}$ Opis dyscypliny „nauki o polityce publicznej”: J. Woźnicki, Nowa dyscyplina - „nauki o polityce publicznej” usytuowana $w$ dziedzinie nauk społecznych, „Nauka” 2012, nr 1, PAN, Warszawa.

${ }^{2}$ Ustawa z dnia 4 września 1997 r. o działach administracji rządowej z późn. zm. http://isap.sejm. gov.pl/DetailsServlet?id=WDU20070650437.

3 P. Łyżwa, Aksjologiczne uwarunkowania polityki jako sfery społecznej-zarys problemu, „Wrocławskie Studia Politologiczne" 2012, nr 13, s. 23-36.

${ }^{4}$ M. Suchanek, Zarządzanie przez wartości w administracji publicznej, „Zeszyty Naukowe Uniwersytetu Szczecińskiego” 2012, nr 772, „Studia Administracyjne”, nr 4.
} 
Odwołując się do definicji encyklopedycznej pojęcia wiedza, odnotujmy, że „wiedza, w szerokim znaczeniu to wszelki zbiór poglądów, wierzeń itp., którym przypisuje się wartość poznawczą lub praktyczną. (...) Wiedza, w węższym znaczeniu, to ogół wiarygodnych informacji o rzeczywistości wraz z umiejętnością ich wykorzystania; w społeczeństwach współczesnych wiedza w tym znaczeniu to przede wszystkim, choć nie wyłącznie, wiedza naukowa"s.

Pojęcie „społeczeństwo wiedzy” odnosimy do tych społeczeństw, które z wiedzy uczyniły zasadniczy zasób i czynnik swojego rozwoju.

Dotyczy to przede wszystkim:

- kreowania i generowania wiedzy w wyniku badań naukowych i innowacji,

- upowszechniania i dystrybucji wiedzy w procesie edukacyjnym,

- wykorzystania wiedzy dla rozwoju ekonomicznego poprzez innowacje, transfer i komercjalizację technologii.

Przez pryzmat pojęcia społeczeństwo wiedzy odwołujemy się do spojrzenia na wiedzę - a w tym jej wytwarzanie, dystrybucję i wykorzystywanie - z punktu widzenia osoby ludzkiej, w ujęciu indywidualnym i zbiorowym (identyfikujemy tu elementy życia społecznego).

Odwołanie się do pojęcia sektor wiedzy prowadzi nas do podejścia do wiedzy z punktu widzenia instytucjonalnego i infrastrukturalnego (odnosimy się tu do sfery życia publicznego i gospodarczego).

Wprowadzone w tym artykule pojęcie sektora wiedzy obejmuje instytucje zajmujące się tworzeniem, przetwarzaniem, archiwizowaniem, udostępnianiem, przekazywaniem i transferem wiedzy, a także właściwe podmioty i zarządzane zasoby o charakterze infrastrukturalnym, istotne z punktu widzenia procesów dotyczących wiedzy. Podejście to nie jest fundamentalnie niezgodne, ale też nie pokrywa się z rozumieniem sektora wiedzy wprowadzonym przez L. Jasińskiego jako obszaru osadzonego w części w tzw. czwartym, a w części w piątym sektorze gospodarki ${ }^{6}$.

Realne uwarunkowania rozwojowe powodują, że społeczeństwo wiedzy kreuje się w ślad za rozwojem sektora wiedzy. Określa to znaczenie systemu edukacji narodowej i badań naukowych, obejmującego oświatę i szkolnictwo wyższe oraz nierozerwalnie z nimi związaną naukę, a szerzej sferę B+R, której społeczna użyteczność obejmuje także funkcje proinnowacyjne.

${ }^{5}$ Nowa Encyklopedia Powszechna PWN, Warszawa 2004.

${ }^{6}$ L. Jasiński, Sektor wiedzy w rozwoju gospodarki, Key Text, Warszawa 2009. 
Społeczeństwo informacyjne stanowi pojęcie osobne. To formacja, w ramach której generowanie, przesyłanie, upowszechnianie i przetwarzanie informacji stanowi najważniejszy rodzaj aktywności ludzkiej

Gospodarkę opartą na wiedzy cechuje dominacja nowej wiedzy jako zasadniczego zasobu produkcyjnego. Dla jej rozwoju dominujące znaczenie mają innowacje, transfer i komercjalizacja technologii oraz zagadnienia własności intelektualnej. Znaczenie sektora wiedzy wynika $\mathrm{z}$ tego, że to jego stan determinuje stopień zaawansowania i rozwoju złożonych procesów kształtowania się społeczeństwa wiedzy i rozwoju gospodarki opartej na wiedzy.

Wiek XX przyniósł przełom w podejściu do wiedzy. Stała się ona istotnym elementem potencjału strategicznego podmiotów instytucjonalnych ${ }^{8}$. Prowadzi nas to w kierunku pojęcia zarządzanie wiedzą. W literaturze można znaleźć różne określenia terminu zarządzanie wiedzą. Według W.R. Bukowitz i R.L. Wiliams: „Zarządzanie wiedzą jest procesem, za pomocą którego organizacja generuje bogactwo oparte na swoich aktywach intelektualnych lub opartych na wiedzy aktywach organizacyjnych"9.

B. Wawrzyniak przytoczył w swojej pracy rozwinięcie definicji stworzonej przez wymienione autorki: „Intelektualne lub oparte na wiedzy aktywa są tutaj rozumiane jako te, które są silnie powiązane z ludźmi lub wywodzą się z procesów, systemów i kultury organizacyjnej, dotyczących marki, organizacji, osobistej wiedzy pracowników, własności intelektualnej, licencji oraz struktur związanych z wiedzą, takich

${ }^{7}$ Przykład właściwego rozumienia relacji społeczeństwo informacyjne - społeczeństwo wiedzy: A.W. Khan (general sub-director of UNESCO for Communication and Information) powiedział: „Information society is the building block for knowledge societies. Whereas I see the concept of »information society « as linked to the idea of "technological innovation «, the concept of »knowledge societies « includes a dimension of social, cultural, economical, political and institutional transformation, and a more pluralistic and developmental perspective. In my view, the concept of »knowledge societies « is preferable to that of the »information society « because it better captures the complexity and dynamism of the changes taking place. (...) the knowledge in question is important not only for economic growth but also for empowering and developing all sectors of society", http://www.unesco.org/new/en/communication-and-information/ resources/news-and-in-focus-articles/all-news/news/towards_knowledge_societies_an_interview_with_ abdul_waheed_khan-2/\#.UzkrmHqqbs0, dostęp 31.03.2014.

8 „Jedynym pewnym źródłem przewag konkurencyjnych jest wiedza. Kiedy zmieniają się rynki, eksplodują nowe technologie, mnożą się konkurenci, a produkty starzeją się prawie w ciągu nocy, przedsiębiorstwami mającymi sukcesy są te, które konsekwentnie tworzą nową wiedzę, rozpowszechniają ją szeroko w całej organizacji i szybko przekształcają w nowe technologie i produkty. Takie działania określa się jako „przedsiębiorstwo kreowane przez wiedzę”, którego jedynym biznesem są systematyczne innowacje", I. Nonaka, 1991, cyt. za: B. Wawrzyniak, Zarządzanie wiedza w przedsiębiorstwach - potrzeba diagnozy, KBN, Warszawa 2001.

9 W.R. Bukovitz, R.L. Williams, The Knowledge Management Fieldbook, Financial Times - Prentice Hall, Pearsons Education Ltd., London 1999, s. 2. 
jak np. banki danych, technologie, powiązania wewnątrzorganizacyjne i z otoczeniem itp." ${ }^{\prime \prime}$.

Jeśli wiedza stała się podstawowym zasobem rozstrzygającym o pozycji i zdolnościach rozwojowych konkurujących ze sobą krajów i obszarów regionalnych, a także przedsiębiorstw i obywateli, to tradycyjna misja uniwersytetu szerzenia i poszerzania wiedzy tym bardziej zachowuje swoją aktualność. Uniwersytet jako instytucja w XXI w. zyskuje tym samym nowe wymiary swej służebności społecznej.

Odpowiedzi na pytania, jak kształtować społeczeństwo wiedzy i jak rozwijać sektor wiedzy, należy poszukiwać w prorozwojowej polityce edukacyjnej, naukowej i proinnowacyjnej, w ich wymiarach krajowym i międzynarodowym. Unia Europejska uznaje tworzenie tzw. Europy wiedzy za jeden ze strategicznych celów Wspólnoty. Polska stara się uczestniczyć w realizacji tego celu, uznając jakość, konkurencyjność i przedsiębiorczość za wiodące wartości w tym procesie.

W tym kontekście należy podkreślić priorytetowe znaczenie takich postulatów jak:

- uznanie procesu kreowania społeczeństwa wiedzy za ważny priorytet polityki rozwojowej kraju,

- nadanie rozwojowi sektora wiedzy wymiaru strategicznego, z uwzględnieniem wymogów podnoszenia jakości, innowacyjności i konkurencyjności międzynarodowej,

- troska o europejski wymiar polityki, w tym integracja i współzależność pomiędzy systemami edukacyjnymi i badań naukowych państw członkowskich UE (wymiar wspólnotowy),

- tendencja do wzrostu budżetowego i pozabudżetowego finansowania edukacji i nauki w Europie oraz tworzenie warunków do rozwoju kreatywności,

- zgodność inwestycji z wizją i strategią rozwojową.

Uwzględnienie celów społecznych w programach rozwojowych sektora wiedzy wymaga - wobec wyzwań cywilizacyjnych przyszłości - aby młodzi Polacy jako obywatele mieli możliwość własnego rozwoju. W tym celu niezbędne jest jednoczesne podnoszenie jakości kształcenia i wyrównywanie szans w dostępie do edukacji, a także planowo prowadzone działania na rzecz wzrostu zatrudnialności w grupie absolwentów szkół wyższych.

10 B. Wawrzyniak, op.cit. 


\section{Struktura instytucjonalna sektora wiedzy w ujęciu funkcjonalnym}

Źródłem nowej wiedzy są przede wszystkim badania naukowe, do których wyników dostęp staje się coraz bardziej otwarty. W sektorze wiedzy wyróżnia się cztery piony badawcze:

- uczelnie akademickie,

- Polską Akademię Nauk,

- instytuty badawcze i inne placówki naukowe,

- centra i komórki badawcze korporacji i przedsiębiorstw oraz firmy innowacyjne.

Ponadto istotną rolę powinny odgrywać centra proinnowacyjne i instytucje upowszechniania wyników badań. W obliczu obserwowanych zjawisk dezintegracji działania wymienionych podmiotów niezbędny jest wysiłek w celu harmonizacji funkcjonowania tego systemu.

Misja społeczna sektora wiedzy jest jednak szersza i obejmuje także inne zadania o wielkiej doniosłości dla rozwoju kraju. Możemy dokonać następującej strukturyzacji instytucjonalnej sektora wiedzy. Obejmuje on cztery grupy podmiotów:

I. Instytucje o misji edukacyjnej

- uniwersytety i inne instytucje akademickie oraz uczelnie zawodowe,

- uniwersytety wirtualne, sieci, konsorcja, związki uczelni,

- instytucje kształcenia ustawicznego, firmy szkoleniowe,

- instytuty i placówki badawcze PAN prowadzące studia doktoranckie i kształcące kadrę naukową.

II. Instytucje o zadaniach naukowo-badawczych i eksperckich

- instytuty naukowe: m.in. resortowe oraz instytucje badawcze o statusie think-tanków prowadzących badania,

- międzynarodowe centra badawcze i inne centra naukowe,

- centra doskonałości,

- konsorcja badawcze i sieci naukowe,

- firmy konsultingowe i instytuty pozarządowe.

III. Instytucje o zadaniach badawczo-wdrożeniowych i koordynacyjnych

- centra badawcze korporacji i innych podmiotów gospodarczych,

- firmy innowacyjne,

- instytuty prowadzące działalność badawczo-rozwojową,

- klastry i jednostki koordynacji programów badawczych (krajowych, międzynarodowych), 
- parki przemysłowo-technologiczne, strefy ekonomiczne, parki wiedzy itp.,

- biznes-parki i centra proinnowacyjne,

- instytucje transferu i komercjalizacji technologii, w tym centra uczelniane.

IV. Instytucje zapewniające infrastrukturę informacyjną i usługi promocyjne

- instytucje gromadzenia i dystrybucji informacji, w tym portale, centra informacji naukowej i biblioteki,

- inne instytucje upowszechniania, przetwarzania i udostępniania wiedzy, np. wydawnictwa,

- agencje informacyjne,

- koncerny medialne, edukacyjne itp.

Zyskiwanie przez wiedzę statusu podstawowego zasobu strategicznego uzasadnia wniosek, że dążenie do powiększania tego zasobu prowadzi do intelektualizacji przedsiębiorstwa ${ }^{11}$. Firma komercyjna będąca „zintelektualizowanym przedsiębiorstwem” także staje się instytucją sektora wiedzy.

Schematyczne przedstawienie sektora wiedzy od strony funkcjonalnej pokazuje Rysunek 1 . Wyróżniono na nim także szczególnie istotne ze względu na specyfikę problematyki polityki proinnowacyjnej narzędzia jej wspierania, bez których - w świetle doświadczeń wielu krajów - niemożliwe jest osiągnięcie sukcesu w tym obszarze.

11 S. Kwiatkowski, Przedsiębiorczość intelektualna, PWN, Warszawa 2000. 


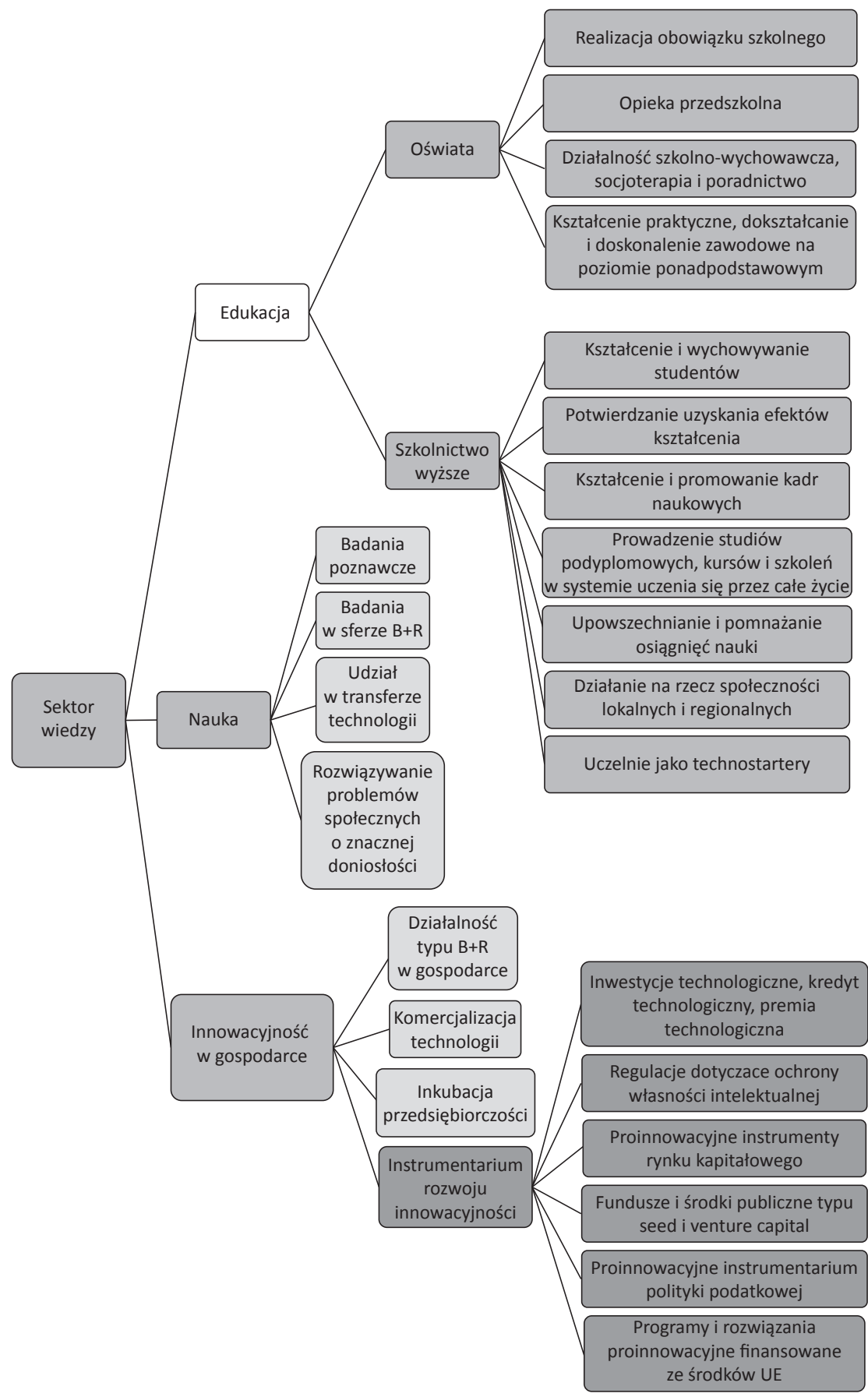

Rysunek 1. Schemat funkcjonalny sektora wiedzy, ze wskazaniem instrumentarium rozwoju innowacyjności

Źródło: opracowanie własne. 
Podkreślenia wymaga zintegrowany charakter sektora wiedzy. Oświata i szkolnictwo wyższe - współkreujące wspólnie sferę edukacji - oraz nauka i innowacje współtworzą powiązaną wzajemnie sferę generowania i udostępniania wiedzy, która ma swoje wyróżnione miejsce w polityce państwa. Polityka podnoszenia jakości kapitału intelektualnego, w tym zwłaszcza kapitału ludzkiego, a także rozwoju sektora wiedzy, powinna mieć charakter zintegrowany i kompleksowy, dla zapewnienia harmonijnej realizacji powiązanych ze sobą zadań funkcjonalnych przypisanych do wszystkich elementów składowych tego sektora. Oznacza to wymóg prowadzenia skoordynowanej i spójnej polityki w oświacie, szkolnictwie wyższym i badaniach naukowych oraz polityki na rzecz rozwoju innowacyjności w gospodarce.

\section{Normy i zasady fundamentalne w sektorze wiedzy. Rola państwa}

Konstytucja Rzeczypospolitej Polskiej z dnia 2 kwietnia 1997 r. zawiera regulacje określające wartości fundamentalne dla procesu kształtowania się sektora wiedzy. Należą do nich m.in. zasady:

- powszechnego i równego dostępu do wykształcenia,

- autonomii szkół wyższych,

- wolności badań naukowych oraz ogłaszania ich wyników,

- wolności nauczania.

Państwo musi być faktycznym, a nie jedynie deklaratywnym, gwarantem tych zasad. Istotą działań ludzkich w sektorze wiedzy jest bowiem twórczość, która musi podlegać ochronie szczególnej, jak widać także konstytucyjnej. Tak określone kanony konstytucyjne muszą pozostawać przedmiotem szczególnej troski społeczności akademickiej i naukowej.

Następujące normy konstytucyjne mają znaczenie dla funkcjonowania sektora wiedzy. Są to zasady:

- zrównoważonego rozwoju - art. 5,

- decentralizacji władzy publicznej - art. 15,

- samorządności społeczeństwa (samorząd terytorialny, środowiskowy, gospodarczy, zawodowy) - art. 16 i 17 ,

- wolności działalności gospodarczej i własności prywatnej, na której oparta jest społeczna gospodarka rynkowa - art. 20,

- powszechnego i równego dostępu do dóbr kultury oraz wykształcenia - art. 6, ust. 1 i art. 70 , ust. 4 , 
- bezpłatności nauki w szkołach publicznych, z uwzględnieniem dopuszczenia świadczenia niektórych usług edukacyjnych za odpłatnością - art. 70, ust. 2,

- autonomii szkół wyższych - art. 70, ust. 5,

- wolności twórczości i badań naukowych - art. 73.

Postanowienia Konstytucji RP dotyczące gospodarki, edukacji, nauki i kultury są zawarte w następujących regulacjach:

\section{Art. 5}

Rzeczpospolita (...) zapewnia ochronę środowiska, kierując się zasadą zrównoważonego rozwoju.

Art. 20

Społeczna gospodarka rynkowa oparta na wolności działalności gospodarczej, własności prywatnej (...) stanowi podstawę rozwoju gospodarczego Rzeczypospolitej Polskiej.

Art. 73

Każdemu zapewnia się wolność twórczości artystycznej, badań naukowych oraz ogłaszania ich wyników, wolność nauczania, a także wolność korzystania z dóbr kultury.

\section{Art. 70}

1. Każdy ma prawo do nauki. Nauka do 18 roku życia jest obowiązkowa. Sposób wykonywania obowiązku szkolnego określa ustawa.

2. Nauka w szkołach publicznych jest bezpłatna. Ustawa może dopuścić świadczenie niektórych usług edukacyjnych przez publiczne szkoły wyższe za odpłatnością.

3. Rodzice mają wolność wyboru dla swoich dzieci szkół innych niż publiczne. Obywatele i instytucje mają prawo zakładania szkół podstawowych, ponadpodstawowych i wyższych oraz zakładów wychowawczych. Warunki zakładania i działalności szkół niepublicznych oraz udziału władz publicznych w ich finansowaniu, a także zasady nadzoru pedagogicznego nad szkołami i zakładami wychowawczymi, określa ustawa.

4. Władze publiczne zapewniają obywatelom powszechny i równy dostęp do wykształcenia. W tym celu tworzą i wspierają systemy indywidualnej pomocy finansowej i organizacyjnej dla uczniów i studentów. Warunki udzielania pomocy określa ustawa.

5. Zapewnia się autonomię szkół wyższych na zasadach określonych w ustawie. 
W świetle przywołanych regulacji, rola państwa w odniesieniu do sektora wiedzy w zakresie celów polega na:

- zapewnianiu prawa do nauki,

- zapewnianiu powszechnego i równego dostępu do wykształcenia oraz wolności nauczania,

- stymulowaniu rozwoju badań naukowych i doskonaleniu mechanizmów ich wykorzystania,

- zapewnianiu autonomii uczelni,

- zapewnianiu wolności badań naukowych oraz ogłaszania ich wyników,

- stosowaniu zasady zrównoważonego rozwoju.

W zakresie sposobów realizacji celów polega na:

- ustalaniu strategii rozwoju, założeń i kierunków oraz realizacji polityki edukacyjnej, a także polityki w zakresie badań naukowych i innowacji - przy współdziałaniu środowiskowych instytucji partnerskich ładu systemowego,

- stanowieniu aktów prawnych, określających działanie systemu edukacji narodowej i systemu badań naukowych,

- sprawowaniu nadzoru nad funkcjonowaniem tych systemów,

- stymulowaniu i zapewnianiu jakości kształcenia i efektywności badań,

- wykonywaniu funkcji regulacyjnych, koordynacyjnych i sprawozdawczych, wynikających z ustaw,

- tworzeniu warunków zapewniania właściwego miejsca kraju na arenie międzynarodowej w obszarze sektora wiedzy, w tym w dziedzinie szkolnictwa wyższego i nauki.

Państwo wypełnia zatem przede wszystkim zadania:

- kreatora systemu instytucji wiedzy i podmiotu określającego ogólne zasady i tryb działania tego systemu (regulacje ustawowe i rozporządzenia),

- podmiotu stwarzającego warunki rozwoju sektora wiedzy i jego wkładu w rozwój kraju, finansującego edukację i badania ze środków publicznych zgodnie z założeniami polityki gospodarczej i naukowej oraz promującego dopływ środków niepublicznych do systemu,

- wewnętrznego i zewnętrznego koordynatora systemu (polityka budżetowa i gospodarcza, polityka naukowa, priorytety, podział środków),

- organu nadzorującego i pielęgnującego w systemie (obowiązek korekty w wypadku pojawiania się objawów niepożądanych),

- gwaranta utrzymania potencjału o strategicznym znaczeniu,

- kreatora warunków spójności w relacji pomiędzy systemem szkolnictwa wyższego i badań naukowych a jego otoczeniem. 
Państwo nie powinno administrować instytucjami sektora wiedzy ani też ingerować w obszar ich mikrozarządzania. W szczególności, nie powinno naruszać zasad autonomii instytucjonalnej - ani wprost, ani pośrednio - poprzez mechanizmy dystrybucji środków publicznych.

\section{Instrumentarium polityki publicznej wobec sektora wiedzy. Zasady i dobre praktyki we współdziałaniu realizatorów polityki publicznej z partnerami środowiskowymi}

Instrumentarium państwa w wypełnianiu jego roli wobec sektora wiedzy obejmuje:

- legislację - warunki prawne powstawania i działania instytucji sektora wiedzy oraz prawa i obowiązki twórców w tym sektorze, w tym władzę o charakterze regulacyjnym, sprawowaną na poziomie systemowym w obszarze szkolnictwa wyższego i badań naukowych, ale także finansów publicznych i gospodarki, w tym innowacyjności,

- narzędzia ekonomiczne sterowania działaniem instytucji, w tym zwłaszcza poziom i sposób finansowania budżetowego oraz reguły gospodarki finansowej,

- nadzór i funkcje kontrolne,

- wpływ na otoczenie instytucji działających w sektorze wiedzy.

Rola państwa wobec instytucji sektora wiedzy powinna być wyraźnie określona, ale ograniczona. Partnerami państwa w realizacji polityki wobec sektora wiedzy powinny być jednak nie tylko przedsiębiorstwa innowacyjne oraz instytucje akademickie i naukowe, ale także partnerzy środowiskowi, w tym organizacje je zrzeszające, a ponadto umocowane w ustawach reprezentatywne organy opiniodawcze, doradcze, przedstawicielskie, korporacje uczonych, organizacje pozarządowe pożytku publicznego, a wśród nich stowarzyszenia i federacje twórców.

Redukując koszty swego działania, państwo w wypełnianiu swoich ról wobec sektora wiedzy wykazuje się pewnym deficytem wydolności i ekspertyzy. Można to wytłumaczyć zasadą odwoływania się do potencjału organizacji tzw. trzeciego sektora (instytucji pozarządowych) jako emanacji roli społeczeństwa obywatelskiego.

Dlatego wobec sektora wiedzy państwo powinno:

- korzystać ze środowiskowych instytucji partnerskich, w tym przekazywać/zlecać część swoich zadań niezależnym profesjonalnym podmiotom gwarantującym jakość dzieła, 
- zapewnić sobie niezależne, kompetentne oraz gwarantujące transparentny i zobiektywizowany charakter działania gremia partnerskie, doradcze i opiniodawcze, także wypełniające role ewaluacyjne i selekcyjne ${ }^{12}$.

Dla rozwoju sektora wiedzy ogromne znaczenie ma zatem samoorganizacja środowisk, w tym ich otwartość na współpracę, niezależność i aktywność. Zasadzie autonomii instytucjonalnej uczelni, instytutów naukowych i organizacji środowiskowych w określonych prawnie ramach, towarzyszyć musi jednak poszanowanie zasad dobra wspólnego, służby publicznej i odpowiedzialności, a także działania w granicach interesu publicznego i dla jego ochrony.

Samorządność i inicjatywy obywatelskie środowisk sektora wiedzy, będąc podporządkowane tym zasadom, muszą respektować wymagania rządności instytucjonalnej, rozliczalności i transparentności, dotrzymywania wymogów etyki zawodowej, etosu i dobrych praktyk w działaniu. Środowiska edukacyjne i naukowe powinny kierować się zasadami bezstronności w życiu publicznym, ale jednocześnie mają one prawo domagać się respektowania przez rządzących reguł państwa prawnego oraz praw i wolności obywatelskich.

Działania organów władzy publicznej nie mogą naruszać wartości i zasad fundamentalnych w sektorze wiedzy. Wiąże się z tym wymóg prowadzenia polityki przewidywalnej oraz respektującej zasady partnerstwa pomiędzy reprezentatywnymi przedstawicielami władz oraz instytucji i środowisk ${ }^{13}$.

Uprawnione oczekiwania wobec organów władzy publicznej obejmują zwłaszcza wymogi dotrzymywania reguł dobrych praktyk w procesie stanowienia prawa w odniesieniu do sektora wiedzy. Zasady te zostały określone w Stanowisku wspólnym Prezydium KRASP, Prezydium PAN oraz Prezydium RGNiSW ${ }^{14}$, w którym czytamy:

1. „wymóg wprowadzania nowych regulacji prawnych w sposób nadążający za obserwowanymi i prognozowanymi zmianami w jego otoczeniu. Działania legislacyjne powinny być prowadzone w sposób przewidywalny dla środowisk akademickich i naukowych przy zapewnieniu regulacji stabilnych w dłuższym okresie;

${ }^{12}$ Np. RGNiSW (Rada Główna Nauki i Szkolnictwa Wyższego), KRASP (Konferencja Rektorów Akademickich Szkół Polskich), KRZaSP (Konferencja Rektorów Zawodowych Szkół Polskich), PAN (Polska Akademia Nauk), PAU (Polska Akademia Umiejętności), RGIB (Rada Główna Instytutów Badawczych), PSRP (Parlament Studentów Rzeczypospolitej Polskiej), KRD (Krajowa Reprezentacja Doktorantów) oraz organizacje twórców, pracodawców i związki zawodowe.

${ }_{13}$ J. Woźnicki, Szkolnictwo wyższe w procesie przemian - zmiany systemowe: 2007-2012, „Kwartalnik Biura Analiz Sejmowych Kancelarii Sejmu Studia BAS” 2013, nr 3(35), s. 71-88.

14 Stanowisko wspólne Prezydium KRASP, Prezydium PAN oraz Prezydium RGNiSW z dnia 5 lipca $2013 \mathrm{r}$. w sprawie zasad prowadzenia prac legislacyjnych dotyczacych szkolnictwa wyższego i nauki, http:// www.krasp.org.pl/pliki/982d2fddbff52900b0425a8f5ca289dd.pdf, dostęp 31.03.2014. 
2. wprowadzanie zmian w ustawach i rozporządzeniach powinno być poprzedzone nie tylko formalnym spełnieniem wymogów konsultacji społecznych, ale przede wszystkim realnym współdziałaniem zainteresowanych ministerstw z przedstawicielami ustawowo umocowanych, reprezentatywnych organów i organizacji działających na szczeblu centralnym w szkolnictwie wyższym i nauce;

3. częste inicjowanie działań legislacyjnych prowadzonych pospiesznie i nierzadko przy braku zrozumienia i poparcia ze strony środowisk akademickich i naukowych, w warunkach braku dialogu w poszukiwaniu najlepszych rozwiązań, prowadzi do niejasności dotyczących stanu prawnego;

4. wprowadzanie regulacji nadmiarowych, wprowadzających przerost wymogów administracyjnych i biurokratyzujących działalność instytucji i pracowników naukowych. Dotyczy to w szczególności nadmiaru i zbyt szczegółowego charakteru rozporządzeń wydawanych często z opóźnieniem naruszającym wymagane zasady techniki legislacyjnej;

5. regulacje ustawowe nie mogą ingerować w statutowe reguły działania organów i organizacji reprezentatywnych w systemie szkolnictwa wyższego".

Kreatorzy i realizatorzy polityki publicznej wobec sektora wiedzy powinni wystrzegać się: „apriorycznego przyjmowania uproszczonej wizji świata akademickiego i naukowego, który z założenia miałby być proefektywnościowo ekonomizowany w wyniku poddania uczelni i instytutów jednocześnie dwóm presjom:

- na poziomie systemowym - presji nadregulacji i cięć budżetowych,

- na poziomie instytucjonalnym - presji ustawowego ingerowania w obszar mikrozarządzania oraz narzucania reguł biznesowego menedżeryzmu, obcych kulturowo uniwersytetowi i ograniczających zdolności twórcze i rozwojowe instytucji naukowych.

W okresie dłuższym byłby to zabieg nieefektywny"15.

Taka strategia musiałaby ustąpić pod presją kultury. Dotyczy to zwłaszcza kultury instytucjonalnej uniwersytetu silnie zakorzenionej w świecie wartości akademickich. Środowisko akademickie cechuje szczególna wrażliwość w tym obszarze.

Na wartości istotne w samych instytucjach akademickich i naukowych społeczność zwraca uwagę w dwóch kluczowych dokumentach:

- w Kodeksie Dobrych Praktyk w Szkołach Wyższych ${ }^{16}$,

$15 \mathrm{~J}$. Woźnicki, Uniwersytet jako kreacja instytucjonalna ambicji twórców i oczekiwań interesariuszy w kierunku zmiany nieniszczącej, materiały Kongresu Kultury Akademickiej, Kraków, 20-22 marca 2014, http://kongresakademicki.pl/dzial/teksty-nadeslane/page/3/, dostęp 21.03.2014.

16 J. Woźnicki, Uczelnie akademickie jako instytucje życia publicznego, FRP, Warszawa 2007; Kodeks Dobrych Praktyk w Szkołach Wyższych opracowany przez Fundację Rektorów Polskich i ogłoszony przez Zgromadzenie Plenarne Konferencji Rektorów Akademickich Szkół Polskich w dniu 26 kwietnia $2007 \mathrm{r}$. 
- w Kodeksie Etyki Pracownika Naukowego ${ }^{17}$.

W pierwszym z tych opracowań wskazano m.in. 10 następujących fundamentalnych zasad, które legły u podstaw tego dokumentu, jakimi winny kierować się organy zarządzające uczelniami:

1. zasada służby publicznej,

2. bezstronności w sprawach publicznych,

3. legalizmu,

4. autonomii i odpowiedzialności,

5. podziału i równowagi władzy w uczelni,

6. kreatywności,

7. przejrzystości,

8. subsydiarności,

9. poszanowania godności i tolerancji,

10. uniwersalizmu badań i kształcenia.

W drugim z kodeksów wskazano zasady samoregulacji społeczności naukowej, w przeświadczeniu, że podstawowym obowiązkiem środowiska jest przestrzeganie ustalonych zasad i cnót pracy naukowej. Są to:

1. „Uniwersalne zasady i wartości etyczne w pracy naukowej: sumienność, wiarygodność, obiektywizm, bezstronność, niezależność, otwartość, przejrzystość, odpowiedzialność, rzetelność, troska, odwaga w sprzeciwianiu się poglądom sprzecznym z wiedzą naukową oraz praktykom niezgodnym z zasadami rzetelności naukowej.

2. Dobre praktyki w badaniach naukowych:

2.1. Praktyki dotyczące postępowania $z$ danymi naukowymi,

2.2. Praktyki dotyczące procedur badawczych,

2.3. Praktyki autorskie i wydawnicze,

2.4. Praktyki dotyczące recenzowania i opiniowania”.

\section{Polityka rozwoju sektora wiedzy na tle nauk o polityce publicznej}

Wskazując specjalności w zakresie nauk o polityce publicznej, należy uwzględniać zróżnicowanie i złożoność polityki w ramach poszczególnych obszarów działania organów władzy publicznej. Kierując się tym założeniem, w opisie nowej dyscypliny

${ }^{17}$ Kodeks Etyki Pracownika Naukowego opracowany przez Komisję ds. Etyki w Nauce i ogłoszony przez Zgromadzenie Ogólne Polskiej Akademii Nauk w dniu 13 grudnia 2012 r. 
przedstawiono następującą listę specjalności naukowych, rozumianych jako jej wyodrębnione obszary badawcze ${ }^{18}$ :

- podstawy nauk o polityce publicznej (podstawy teoretyczne i metodologiczne),

- instrumenty polityki publicznej i ich zastosowanie (instrumenty prawne, planistyczne, organizacyjne, kontrolne i inne),

- polityka rozwoju społeczeństwa wiedzy (polityka wzrostu kapitału intelektualnego, pomnażania dorobku kulturowego oraz rozwoju sektora wiedzy),

- polityka społeczna (społeczna, spraw rodziny, rozwoju rynku pracy i ochrony zdrowia),

- polityka gospodarcza (budżetu i finansów publicznych, gospodarki, wzrostu potencjału gospodarczego, rozwoju usług i zasobów oraz ochrony środowiska),

- polityka spraw wewnętrznych i zagranicznych (zagraniczna, bezpieczeństwa i spraw wewnętrznych, sprawiedliwości i ochrony praw obywatelskich).

Jako możliwe podobszary/specjalizacje badawcze zostały wyróżnione:

- polityka edukacyjna: badania oświatowe i badania nad szkolnictwem wyższym,

- polityka naukowa,

- polityka innowacyjna,

- polityka kulturalna i ochrony dziedzictwa narodowego,

- polityka informacyjna,

- polityka cyfryzacji kraju (telekomunikacja i informatyzacja).

Zauważmy, że wśród zaproponowanych w opisie nowej dyscypliny obszarów badawczych wyróżnionych jako jej specjalności naukowe, znajdujemy politykę rozwoju sektora wiedzy. Wiele ze wskazanych obszarów polityki dotyczy tego sektora. $\mathrm{Na}$ jego rzecz realizowane są liczne projekty i przedsięwzięcia. Warto wymienić w tym miejscu przykładowe - aktualnie realizowane z udziałem autora - projekty badawcze, których rezultaty mogą stać się przydatne w kreowaniu rodzajów polityki publicznej składających się na politykę rozwoju szkolnictwa wyższego jako fundamentalnego elementu składowego sektora wiedzy.

1. Prace prowadzone przez think-tank FRP-ISW na zamówienie i z udziałem KRASP ${ }^{19}$

- Program rozwoju szkolnictwa wyższego do 2020 r. - cztery projekty:

- przygotowanie raportu poświęconego deregulacji w systemie szkolnictwa wyższego,

18 J. Woźnicki, Nowa dyscyplina..., op.cit.; http://www.ck.gov.pl/index.php/komunikaty-ck/247-k-om-u-n-i-k-a-t-n-r-12012, dostęp 31.03.2014.

${ }^{19}$ FRP - Fundacja Rektorów Polskich, ISW - Instytut Społeczeństwa Wiedzy, KRASP - Konferencja Rektorów Akademickich Szkół Polskich. 
- opracowanie dokumentu pt. Nowa stużebność uczelni wXXI wieku - deklaracja KRASP (KRePSZ),

- uzupełniona diagnoza stanu szkolnictwa wyższego w Polsce,

- finansowanie szkół wyższych ze środków publicznych - studia, analizy, koncepcje realizacji (zróżnicowanie finansowania jako narzędzie dywersyfikacji uczelni, finansowanie projakościowe/oparte na wskaźnikach efektywności, kontraktowe, konkursowe).

- Piąty poziom Krajowych Ram Kwalifikacji ${ }^{20}$.

- Projekt polsko-ukraiński Analiza na wybranych przykładach wspótpracy uczelni polskich i ukraińskich na tle porównania systemów szkolnictwa wyższego. Wnioski i rekomendacje $e^{21}$.

- Program Benchmarking w systemie szkolnictwa wyższego 22 .

2. Prace własne Rady Głównej Nauki i Szkolnictwa Wyższego określone w uchwale Rady z dnia 13 kwietnia 2014 r. $^{23}$ obejmują zagadnienia odbiurokratyzowania systemu kształcenia, w tym Krajowych Ram Kwalifikacji, z uwzględnieniem treści regulacji i stosowanych praktyk oraz modeli studiów doktoranckich i uwarunkowań mobilności młodych naukowców.

Zakres problemów będących przedmiotem tych prac został przyjęty w nawiązaniu do działań Ministerstwa Nauki i Szkolnictwa Wyższego, ale także opracowania i ogłoszenia w 2009 r. przez Konsorcjum KRASP(KRePSZ)-FRP-KRZaSP Strategii rozwoju szkolnictwa wyższego 2010-2020: projektu środowiskowego ${ }^{24}$, który został uznany w pracach Ministerstwa za dokument podstawowy dla określenia programu rozwoju szkolnictwa wyższego na potrzeby realizacji polityki publicznej rządu wobec sektora wiedzy.

W nadchodzących latach niezbędne jest ogłoszenie programu rozwoju sektora wiedzy w Polsce. Można spodziewać się konkretnych propozycji ze strony KRASP, RGNiSW i FRP w tym zakresie. Osiągnięcie sukcesu w procesie realizacji takiego programu wymagać będzie wsparcia ze strony najwyższych organów państwa oraz zawarcia porozumienia środowiskowego, bez którego kolejne zmiany byłoby znacznie

${ }^{20}$ Projekt realizowany wspólnie z firmą Pearson Central Europe.

${ }^{21}$ Projekt współfinansowany przez PKN ORLEN.

22 Projekt realizowany wspólnie z firmą ORANGE Polska.

${ }^{23}$ Uchwała nr 1/2014 Prezydium Rady Głównej Nauki i Szkolnictwa Wyższego z dnia 12 marca 2014 r. ustalająca roczny plan pracy Rady na 2014 rok.

${ }^{24}$ Strategia rozwoju szkolnictwa wyższego 2010-2020: projekt środowiskowy, Konferencja Rektorów Akademickich Szkół Polskich (Konferencja Rektorów Publicznych Szkół Zawodowych), Fundacja Rektorów Polskich, Konferencja Rektorów Zawodowych Szkół Polskich, 2009. 
trudniejsze do wprowadzenia. Takie porozumienie jest możliwe, ponieważ rząd ma do czynienia ze zdolnymi do wspólnego działania partnerami środowiskowymi. Nigdy przedtem nie było tak, aby wszystkie reprezentatywne instytucje działające na szczeblu centralnym w szkolnictwie wyższym i nauce potrafiły ze sobą tak dobrze współdziałać na rzecz celów rozwojowych kraju. Partnerzy środowiskowi istnieją i są gotowi do współpracy ${ }^{25}$. Stwarza to warunki do tego, żeby szkolnictwo wyższe mogło w perspektywie do 2020 r. stać się dźwignią rozwojową kraju i źródłem jego prestiżu. Wymaga to jednak przyjęcia nowej perspektywy strategicznej rozwoju sektora wiedzy z odwołaniem się do aksjologicznych uwarunkowań polityki publicznej, uwzględniającej agendę finansową UE 2014-20.

\section{Bibliografia}

Adams D., Usable Knowledge in Public Policy, "Australian Journal of Public Administration" 2004, no. 63.1.

Borowiec M., Rola szkolnictwa wyższego w procesie kształtowania gospodarki opartej na wiedzy, „Przedsiębiorczość - Edukacja” 2008, nr 4.

Bukovitz W.R., Williams R.L., The Knowledge Management Fieldbook, Financial Times - Prentice Hall, Pearsons Education Ltd., London 1999.

Bukowski M., Szpor A., Śniegocki A., Potencjał i bariery polskiej innowacyjności, Instytut Badań Strukturalnych, Warszawa 2012.

The Network Society: from Knowledge to Policy, red. M. Castells, G. Cardoso, Center for Transatlantic Relations, Paul H. Nitze School of Advanced International Studies, Johns Hopkins University, 2006.

Dawes S., Cresswell A., Pardo T., From "need to know" to "need to share": Tangled Problems, Information Boundaries, and the Building of Public Sector Knowledge Networks, "Public Administration Review" 2009, nr 69.3.

Dorocki S., Gospodarka oparta na wiedzy w założeniach strategii lizbońskiej - na przykładzie Francji, „Przedsiębiorczość - Edukacja” 2008, nr 4.

Dworak E., Gospodarka oparta na wiedzy według metodologii organizacji międzynarodowych, „Wiadomości Statystyczne” 2009, nr 9.

Goban-Klas T., Sienkiewicz P., Społeczeństwo informacyjne: Szanse, zagrożenia, wyzwania, Fundacja Postępu Telekomunikacji, Kraków 1999.

Górzyński M., Innowacyjność polskiej gospodarki w kontekście integracji z UE: możliwości i bariery wdrażania w Polsce gospodarki opartej na wiedzy, CASE - Centrum Analiz Społeczno-Ekonomicznych, Warszawa 2004.

${ }^{25}$ Apel KRASP, RGNiSW, KRZaSP, FRP z dnia 11 stycznia 2013 do Parlamentu i Rządu Rzeczypospolitej Polskiej, http://forum.forumakademickie.pl/aktualnosci/2013/2/1/1322/apel-do-parlamentu-irzadu-rzeczypospolitej-polskiej/. 
Jasiński L., Sektor wiedzy w rozwoju gospodarki, Key Text, Warszawa 2009.

Kodeks „Dobre praktyki w szkołach wyższych”, FRP, KRASP, Kraków czerwiec 2007, http://www. frp.org.pl/?page=zakonczone_projekty_frp\&projekt=6, dostęp 26.03.2014.

Kodeks Etyki Pracownika Naukowego, Komisja ds. Etyki w Nauce, 13 grudnia 2012 roku, https:// amu.edu.pl/_data/assets/pdf_file/0019/165700/Kodeks_etyki_pracownika_naukowego. pdf, dostęp 26.03.2014.

Kwiatkowski S., Przedsiębiorczość intelektualna, PWN, Warszawa 2000.

Leydesdorff L., The Triple Helix-University-industry-government Relations: A Laboratory for Knowledge Based Economic Development, "East Review” 1995, nr 14.1.

Luen T., Al-Hawamdeh S., Knowledge Management in the Public Sector: Principles and Practices in Police Work, "Journal of Information Science" 2001, nr 27.5.

Łyżwa P., Aksjologiczne uwarunkowania polityki jako sfery społecznej - zarys problemu, „Wrocławskie Studia Politologiczne” 2012, nr 13.

Macek I., Aksjologiczne uwarunkowania procesu decyzyjnego w administracji publicznej, w: Administracja i polityka. Proces decyzyjny w administracji publicznej, red. L. Habuda, Wrocław 2000.

Okoń-Horodyńska E., Piech K., Strategia lizbońska a możliwości budowania gospodarki opartej na wiedzy w Polsce - wnioski i rekomendacje, Wydawnictwo Polskiego Towarzystwa Ekonomicznego, Warszawa 2005.

Riege A., Lindsay N., Knowledge Management in the Public Sector: Stakeholder Partnerships in the Public Policy Development, "Journal of Knowledge Management” 2006, nr 10.3.

Stanowisko wspólne Prezydium KRASP, Prezydium PAN oraz Prezydium RGNiSW z dnia 5 lipca 2013 r. w sprawie zasad prowadzenia prac legislacyjnych dotyczacych szkolnictwa wyższego i nauki, http://www.krasp.org.pl/pliki/982d2fddbff52900b0425a8f5ca289dd.pdf, dostęp 31.03.2014.

Strategia rozwoju szkolnictwa wyższego 2010-2020: projekt środowiskowy, Konferencja Rektorów Akademickich Szkół Polskich (Konferencja Rektorów Publicznych Szkół Zawodowych), Fundacja Rektorów Polskich, Konferencja Rektorów Zawodowych Szkół Polskich, 2009, http://www.frp.org.pl/pliki/Strategia_rozwoju_szkolnictwa_wyzszego_2010_2020_projekt_srodowiskowy.pdf, dostęp 26.03.2014.

Suchanek M., Zarządzanie przez wartości w administracji publicznej, „Zeszyty Naukowe Uniwersytetu Szczecińskiego" 2012, nr 772, Studia Administracyjne nr 4.

Wawrzyniak B., Zarządzanie wiedza w przedsiębiorstwach - potrzeba diagnozy, KBN 2001.

Woźnicki J., Nowa dyscyplina - „nauki o polityce publicznej” usytuowana $w$ dziedzinie nauk społecznych, „Nauka” Polskiej Akademii Nauk 2012, nr 1.

Woźnicki J., Szkolnictwo wyższe w procesie przemian - zmiany systemowe: 2007-2012, „Studia BAS” 2013, nr 3(35).

Woźnicki J., Uczelnie akademickie jako instytucje życia publicznego, FRP, Warszawa 2007. 
Woźnicki J., Uniwersytet jako kreacja instytucjonalna ambicji twórców i oczekiwań interesariuszy w kierunku zmiany nieniszczącej, materiały Kongresu Kultury Akademickiej, Kraków 20-22 marca 2014, http://kongresakademicki.pl/dzial/teksty-nadeslane/page/3/, dostęp 21.03.2014.

Zioło Z., Ekonomiczne i społeczne uwarunkowania rozwoju gospodarki opartej na wiedzy, „Przedsiębiorczość - Edukacja” 2008, nr 4. 